\title{
A MODEL OF KNOWLEDGE SHARING IN POLISH MANUFACTURING ENTERPRISES
}

\author{
Justyna PATALAS-MALISZEWSKA
}

Faculty of Mechanical Engineering, University of Zielona Góra, Poland

e-mail: j.patalas@iizp.uz.zgora.pl

\begin{abstract}
This article elaborates on a model of knowledge sharing in Polish manufacturing enterprises. The author aims to analyse the effectiveness of knowledge sharing in Polish manufacturing enterprises based on the research results gained from the study described in this paper. In particular, the likely consequences and results of knowledge sharing by using Web 2.0 technologies are studied. This is followed by a discussion on the results of the literature and empirical studies. The summary indicates potential directions for further work.
\end{abstract}

Keywords: knowledge sharing, Web 2.0 technologies, effectiveness.

1

Introduction

The design of a business model of a company is of major importance for entrepreneurial ventures [37]. The essence of a business model is in defining the manner in which a business delivers value to customers, entices customers to pay for that value and converts those payments to profit [32]. About $\$ 31.5$ billion is lost per year by Fortune 500 companies as a result of failing to share knowledge [1]. Knowledge sharing is critical to the success of a firm in today's highly competitive environment [10]. Because of the potential benefits that can be obtained from knowledge sharing e.g. reductions in production costs, firm innovation capabilities etc. [22]; [21] many enterprises have invested in systems and/or tools that can be used to facilitate the sharing of knowledge.

Shared knowledge, vectored mainly through IT technologies, can enhance the effectiveness of internal business processes in enterprises as compared to those processes which are carried out without these technologies. IT resources consist of a combination of technical skills and generic information [28]. Knowledge management in enterprises has evolved from traditional IS (information systems) implementations (monolithic, centralised, controlled) to implementations based on social media and collaborative sharing: Web 2.0, social media, online communities, etc. [23]. Paroutis and Al Saleh (2009) [25] show that Web 2.0 technologies, including blogging and other social media applications, have helped people to share what they considered to be knowledge in an effective and efficient way.
The value of companies has traditionally been judged on the basis of their financial assets, property or other tangible assets. Today, a competitive advantage is viewed as being based on the knowledge of workers. Intangibles such as brand names, patents, copyrights and R\&D spending are now a significant part of the assets of many companies [26]. National statistics on the state of Polish manufacturing enterprises indicate that an increase in production was recorded in 19 out of 22 test subjects, the largest increases in production were in transport equipment (39.1\%), metal products and furniture (18.2\%). Declines were recorded in the manufacture of pharmaceutical products $(12.2 \%)$, manufacture of computer, electronic and optical products $(7.0 \%)$ and machinery and equipment (2.9\%) [Polish Central Statistical Office, 2011].

The author discusses the issue of the tools which were used to facilitate the sharing of knowledge in Polish manufacturing enterprises in order to improve their efficiency. This article addresses the following research questions: Do Polish manufacturing companies really use Web 2.0 technologies? What is the efficiency of a company and why has it become an issue associated with the use of Web 2.0? What is the actual impact on the efficiency of Polish manufacturing companies of those Web 2.0 technologies that are actually used? Some of these issues will be illustrated based on data collected from 25 Polish manufacturing companies.

According to Etzioni [9], organisational efficiency can essentially be defined as the extent to which an organisation accomplishes its goals. Understanding the purpose of knowledge sharing in an enterprise allows for a definition of its effectiveness as consisting of the benefits that can be obtained from using Web 2.0 technologies. To achieve a more contextually rooted 
discussion, this paper explores the perceptions of the potential of Web 2.0 among employees in Polish manufacturing companies. This paper also explores the influences that impact the way manufacturing companies perceive Web 2.0, and thereby how these influences may facilitate or inhibit thinking about Web 2.0 use in knowledge sharing within such companies.

The structure of this paper is as follows. The following section introduces the theoretical framework consisting of tools which are used to facilitate the sharing of knowledge and improve the efficiency of a company. The subsequent methodology section provides the details of data collection used in the study. The third section presents the measures and research methods and the fourth presents the results and findings of the analyses. The final section summarises the conclusions of the study and provides potential implications for future research.

\section{Theoretical background and hypotheses}

\subsection{Knowledge sharing in the manufacturing enterprises}

Knowledge sharing in manufacturing companies is not an easy task. But accurate knowledge is one of the key issues which affects the success of a business organisation [11]. Knowledge sharing is a process in which knowledge and skills are transferred from one individual to another [21]. Chaudhry [5] discovered that effective knowledge sharing practises allow individuals to reuse and regenerate knowledge at the individual and organisational level. I agree with Barson [2] that there exist individual barriers in knowledge sharing, but also with Bureš [4] who found that such barriers at the organisational level.

According to my research conducted in Polish manufacturing companies in the construction and automotive industries, $52 \%$ of respondents defined production difficulties resulting from problems in knowledge sharing within the company in the form of insufficient organisation of the company and a lack of communication between the company employees. More than $30 \%$ identify that a reluctance to share knowledge is a continuous factor in production problems. A Knowledge Management System (KMS) can effectively facilitate knowledge sharing by helping to remove some of the barriers, for instance, a lack of accessibility to organisational knowledge and physical distance between members [17].
According to Nonaka and Takeuchi [24] and to Polanyi [27], human experience is the foundation of tacit knowledge sharing. On the other hand, mechanisms such as procedure, formal language, handbooks and information technology systems will promote the willingness of employees to share their explicit knowledge [6], [13]. Zahra, Neubaum and Larrañeta [35] assumed that knowledge sharing can be done through informal, unsystematic and non-daily routines within an organisation. Tampoe [31] discovered that motivation for knowledge sharing mainly comes from personal growth, operational autonomy, task achievement and money. Tacit knowledge is basically composed of the following five elements: the technical element, the experiential element, the cognitive element, the emotional element and the faith element [20]. I believe that explicit knowledge must be supported by tacit knowledge. In this study, I will try to define the technologies that can be exploited for knowledge sharing - both tacit and explicit, that could be exploited in Polish manufacturing companies.

\subsection{Web 2.0 technologies for knowledge sharing}

Huang, Chen, Kuo, and Jeng state [14] that most Web 2.0 websites are free and have made it easy for users to create a personal space where they can share information immediately or transmit information more rapidly than by other more conventional means. Boulos and Wheeler [3] define Web 2.0 as the 'social web' and Hemmi, Bayne and Land [12] as the 'read/write web'. In order to explore the impact of Web 2.0 on increasing the efficiency of business processes in manufacturing companies, one can start by reviewing and building on the literature which examines the role of online communities in supporting knowledge sharing in companies. Erat, Desouza, Schafer-Jugel and Kurzawa [8] discussed how different types of communities of practise (e.g. B2C, C2C) can be used for acquiring and sharing knowledge in order to improve business processes and performance. On the other hand, Li and Stromberg [19] discovered that the benefits of blogs for firms are search engine optimisation; e-word-of-mouth (eWOM); improved brand perception and visibility; instantaneous client feedback; market research and insight; increased sales efficiency and a reduced impact from negative user-generated content. Web 2.0 platforms are emerging as a viable channel of knowledge building for general and discipline-specific communities [16]. Knowledge sharing 
using Web 2.0 can be carried out through technologies such as VoIP, e-mail, tagging, phone/videoconferencing, blogs, wiki pages and instant messaging to support processes, including through dialogues and discussions.

\subsection{The effectiveness of internal business processes in manufacturing companies}

According to Law and Ngai [18], it can be stated that knowledge sharing is positively associated with improvements in business processes. The goalattainment approach (one of the number of models for measuring organisational efficiency) considers organisational processes as a whole. Upton [33] stated that decisions in manufacturing companies, such as the timing and quantity of stock procured, manufactured, stored, and delivered, have a significant influence on company performance. Knowledge sharing with the exploitation of available technology will undoubtedly reduce the risk of erroneous decisions in enterprises.

Furthermore, Velasquez et al. [34] claimed that conflict could arise in manufacturing decisions due to incomplete or inaccurate information. The development of information technologies in the late 20th century and 21st centuries in many states, including Poland, changed and continues to change information flows [15] [36]. Today, as corporative information is emerging, the problems of the efficient use of information technology are clearly of paramount importance. Already Simon [29] suggested that the use of information technology can improve organisational efficiency. I agree with Syuntyurenko [30] that information technologies are the foundation of an entirely new level in the development of civilisation, the same can be said regarding their impact on business enterprises. National statistics on the information level of Polish enterprises show that they use information technologies such as Manufacturing Execution Systems (MES) - 24\% of all enterprises, Customer Relationships Management (CRM) - 23\%, Business Intelligence (BI/Controlling) $18 \%$, Business Process Management (BPM) - 4\%, Supply Chain Management (SCM) - 11\%, Product Lifecycle Management (PLM) $-7 \%$.

Devaraj and Kohli [7] believed that investment in technology has been treated by the literature as a black box and its impact on business performance measured with little context. On the other hand Zhang et al. found a positive relationship between IT investment and financial performance in export-focused companies in China.

Therefore, before the survey was carried out, the benefits of using Web 2.0 technologies for knowledge sharing in Polish manufacturing enterprises were defined by five managers, and the survey items were modified based on their feedback. As a result, the following benefits were identified: increased competitiveness, increased quality of products, increased customer satisfaction, faster responses to customer needs, easier and faster access to information, increased employee motivation, time saving, cost reduction, increased work productivity.

Therefore, this study expects that knowledge sharing in Polish manufacturing companies will positively influence their efficiency which in turn leads to the first hypothesis.

H1. Knowledge sharing in Polish manufacturing companies positively influences their efficiency.

Factors of efficiency in the manufacturing companies were based on feedback surveys and their sources are listed here:

- Efficiency: The degree to which a company benefits from the use of Web 2.0 technologies for knowledge sharing in enterprises:

- Effic-factor1: I know that in my organisation the use of Web 2.0 technologies is not very important for the company's success.

- Effic-factor2: I know that in my organisation the use of Web 2.0 technologies is quite important for the company's success.

- Effic-factor3: I know that in my organisation the use of Web 2.0 technologies is very important for the company's success.

- Knowledge sharing in the enterprise: The degree of contact between employees by which one employee can help to transform the knowledge and skills of another [21]:

- KnowShare1: I share my know-how from work with colleagues in my organisation infrequently.

- KnowShare2: I share my know-how from work with colleagues in my organisation frequently.

- KnowShare3: I share my know-how from work with colleagues in my organisation very frequently. 
When employees use Web 2.0 technologies for knowledge sharing they feel more motivated to share knowledge. Hence, this leads to hypotheses $\mathrm{H} 2 \mathrm{a}$ and $\mathrm{H} 2 \mathrm{~b}$.

H2a: The sharing of tacit knowledge between employees positively influences the efficiency of a company.

H2b: The sharing of explicit knowledge between employees positively influences the efficiency of a company.

The factors of the tacit knowledge of employees in manufacturing companies in terms of the use of Web 2.0 technologies were based on feedback surveys and sources which are listed here:

The tacit knowledge of employees: The degree to which an employee believes that he or she shares his/her knowledge with other company employees:

- EtacitK1: I share my knowledge using Web 2.0 technologies infrequently,

- EtacitK2: I share my knowledge using Web 2.0 technologies frequently,

- EtacitK3: I share my knowledge using Web 2.0 technologies very frequently.
The factors of the explicit knowledge of employees in manufacturing companies in terms of the use of Web 2.0 technologies were based on feedback surveys and sources which are listed here:

The explicit knowledge of employees: The degree to which an employee believes that he or she shares his/her knowledge with other company employees:

- ExplicitK1: I share my work reports and official documents using Web 2.0 technologies infrequently,

- ExplicitK2: I share my work reports and official documents using Web 2.0 technologies frequently,

- ExplicitK3: I share my work reports and official documents using Web 2.0 technologies very frequently.

The aim of this study is to explore the impact of knowledge sharing on the efficiency of Polish manufacturing companies. As presented in Figure 1, the research model posits, from the preceding argument, that both employee-based tacit and explicit knowledge sharing in Polish manufacturing enterprises will have a positive influence upon the defined benefits in these firms.

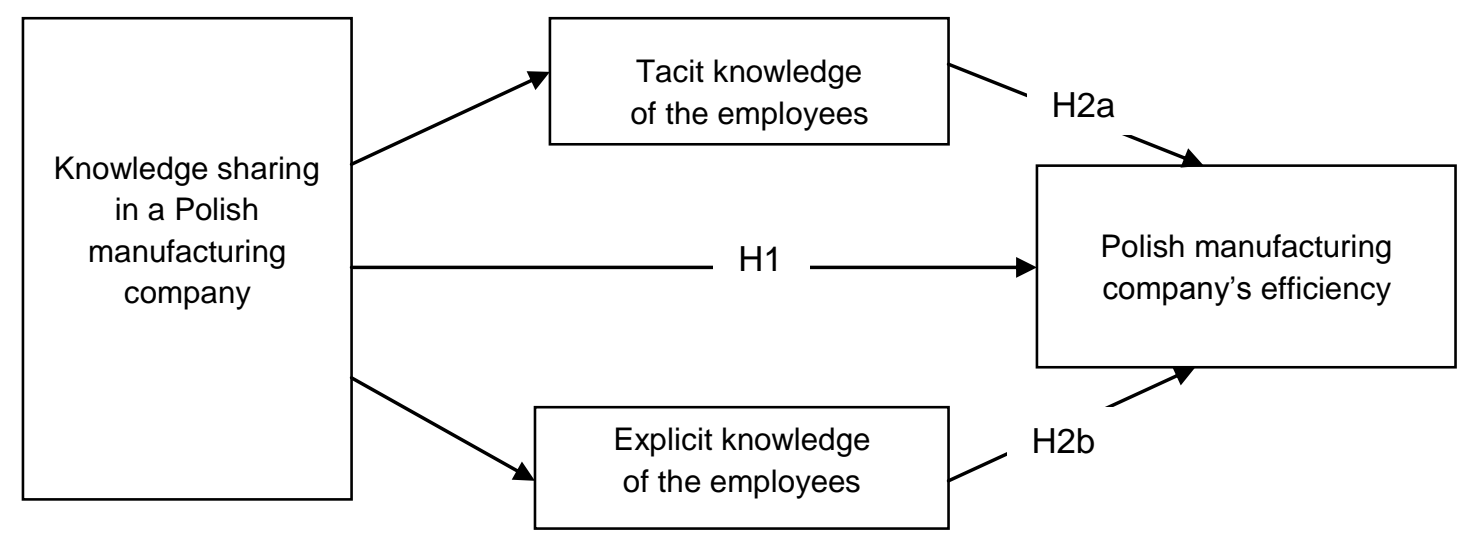

Figure 1. Research model

The following section describes the item measurement and data collection carried out in my research.

\section{$3 \quad$ Measures and method}

The objective of this study was to investigate on how knowledge sharing using Web 2.0 technologies can increase effectiveness in the Polish manufacturing companies. The survey for testing the research model was developed by defining scales to fit the knowledge sharing context. A three-point scale was used for all survey items, ranging: 'disagree' (one point), 'agree' (two points), 'strongly agree' (three points). The data for this study were collected from 25 Polish manufacturing companies (see Table 1).

The survey was conducted in April 2013 through the use of direct interviews with respondents. 
Table 1: Profile of companies and respondents

\begin{tabular}{|c|c|c|c|}
\hline & Items & $\begin{array}{r}\text { Fre } \\
(1\end{array}$ & $\begin{array}{l}\text { lency } \\
25)\end{array}$ \\
\hline \multirow{3}{*}{ Industry } & Construction & 12 & $(48 \%)$ \\
\hline & Automotive & 8 & $(32 \%)$ \\
\hline & Others & 5 & $(20 \%)$ \\
\hline \multirow{4}{*}{$\begin{array}{l}\text { Department of the company } \\
\text { in which the respondent works }\end{array}$} & Manager & 20 & $(80 \%)$ \\
\hline & Research and Development & 2 & $(8 \%)$ \\
\hline & Marketing and sales & 3 & $(12 \%)$ \\
\hline & Others & 0 & $(0 \%)$ \\
\hline
\end{tabular}

\section{Research results and structural model}

The research model was analysed using a correlation and further regression approach in order to estimate the effect of knowledge sharing between employees in Polish manufacturing companies. A moderated correlation approach using Statistica ver. 10.0 was used to test the hypotheses. The data were carefully examined with respect to linearity, equality of variance and normality. No significant deviations were detected. Table 2 presents descriptive correlations for the main variables. The study tests the hypotheses using correlation analysis because an interaction effect exists only if the interaction term makes a significant contribution.

Table 2 presents descriptive correlations for the main variables. This includes the results of the correlation analyses which estimate the effect of knowledge sharing in Polish manufacturing companies - both tacit and explicit - as well as their interaction on the efficiency of a company. The primary interaction of knowledge sharing makes a significant contribution to one of the main benefits of the use of Web 2.0 technologies for knowledge sharing in enterprises, namely: saving time (corr $=0.418621)$. The second interaction of tacit knowledge is also significant and substantially represents the other main benefits from the use of Web 2.0 technologies for knowledge sharing in enterprises: increased competitiveness (corr $=-0.449430$ ) and increased quality of products (corr $=-0.422687$ ). The third interaction of explicit knowledge sharing makes a significant contribution to one of the main benefits of the use of Web 2.0 technologies for knowledge sharing in enterprises, namely: saving time $($ corr $=0.447911)$.

To determine the nature of significant interactions of tacit and explicit knowledge sharing in Polish manu- facturing enterprises, the study tests the hypotheses using regression analyses which estimate the effect of knowledge sharing on the efficiency of a company. Furthermore, the effect of knowledge sharing on the dependent variable for values of benefits from the use of Web 2.0 technologies is analysed.

Table 2 and Fig. 2 show the results of the first hypothesis which tests the structural relationship between the latent variables. For H1, I examined the effects of knowledge sharing in Polish manufacturing companies on their efficiency, respectively. As Table 2 and Fig. 2 show the effect of using information exchange forums and has the value: 0.418621 , by this it is evident that the hypothesis was supported and that there are clear benefits to the use of information sharing among employees using Web 2.0 technologies. To determine the nature of this significant interaction, the study plots the effect (see Fig. 2): company efficiency: saving time $=1.1733+0.41111$ as a result of using information exchange forums. The company efficiency: saving time clearly increases with knowledge sharing in Polish manufacturing companies, when facing high values for using information exchange forums. However, when given low values for using the information exchange forums, a decrease in company efficiency is evident. This finding offers support for hypothesis $\mathrm{H} 1$.

Contrary to hypothesis $\mathrm{H} 2 \mathrm{a}$, tacit knowledge sharing has an effect on company efficiency, but is not positively correlated. As Table 2 and Figs. 3 and 4 show, the effect of using an expert catalogue on the benefits of the use of Web 2.0 technologies for knowledge sharing in enterprises, such as increased competitiveness, has the value 0.449430 and increased quality of products, has the value -0.422687 . Therefore, this hypothesis was not supported. 
Table 2. Correlations analysis

\begin{tabular}{|c|c|c|c|c|c|}
\hline Construct & Item/Factoy & Correlation & r2 & $\mathbf{t}$ & $\mathbf{p}$ \\
\hline $\begin{array}{l}\text { Information Exchange Forums } \\
\text { Increased competitiveness }\end{array}$ & $\begin{array}{l}\text { KnowShare1/KnowShare2/ KnowShare3 } \\
\text { Effic-factor1/Effic-factor2/ } \\
\text { Effic-factor3 }\end{array}$ & -0.013700 & 0.000188 & -0.06571 & 0.948178 \\
\hline $\begin{array}{l}\text { Information Exchange Forums } \\
\text { Increased quality of products }\end{array}$ & $\begin{array}{l}\text { KnowShare1/KnowShare2/ KnowShare3 } \\
\text { Effic-factor 1/Effic-factor2/ } \\
\text { Effic-factor3 }\end{array}$ & 0.119334 & 0.014241 & 0.57642 & 0.569928 \\
\hline $\begin{array}{l}\text { Information Exchange Forums } \\
\text { Increased Customer Satisfaction }\end{array}$ & $\begin{array}{l}\text { KnowShare1/KnowShare2/ KnowShare3 } \\
\text { Effic-factor1/Effic-factor2/ } \\
\text { Effic-factor3 }\end{array}$ & 0.046225 & 0.002137 & 0.22192 & 0.826331 \\
\hline $\begin{array}{l}\text { Information Exchange Forums } \\
\text { Faster response to customer needs }\end{array}$ & $\begin{array}{l}\text { KnowShare1/KnowShare2/ KnowShare3 } \\
\text { Effic-factor1/Effic-factor2/ } \\
\text { Effic-factor3 }\end{array}$ & -0.131306 & 0.017241 & -0.63522 & 0.531552 \\
\hline $\begin{array}{l}\text { Information Exchange Forums } \\
\text { Easier and faster access to the } \\
\text { information }\end{array}$ & $\begin{array}{l}\text { KnowShare1/KnowShare2/ KnowShare3 } \\
\text { Effic-factor1/Effic-factor2/ } \\
\text { Effic-factor3 }\end{array}$ & 0.150329 & 0.022599 & 0.72924 & 0.473216 \\
\hline $\begin{array}{l}\text { Information Exchange Forums } \\
\text { Increased Employee motivation }\end{array}$ & $\begin{array}{l}\text { KnowShare1/KnowShare2/ KnowShare3 } \\
\text { Effic-factor1/Effic-factor2/ } \\
\text { Effic-factor3 }\end{array}$ & -0.251976 & 0.063492 & -1.24873 & 0.224326 \\
\hline $\begin{array}{l}\text { Information Exchange Forums } \\
\text { Saving time }\end{array}$ & $\begin{array}{l}\text { KnowShare1/KnowShare2/ KnowShare3 } \\
\text { Effic-factor1/Effic-factor2/ } \\
\text { Effic-factor3 }\end{array}$ & 0.418621 & 0.175243 & 2.21066 & 0.037279 \\
\hline $\begin{array}{l}\text { Information Exchange Forums } \\
\text { Cost reduction }\end{array}$ & $\begin{array}{l}\text { KnowShare1/KnowShare2/ KnowShare3 } \\
\text { Effic-factor1/Effic-factor2/ } \\
\text { Effic-factor3 }\end{array}$ & 0.012155 & 0.000148 & 0.05830 & 0.954014 \\
\hline $\begin{array}{l}\text { Information Exchange Forums } \\
\text { Increased work productivity }\end{array}$ & $\begin{array}{l}\text { KnowShare1/KnowShare2/ KnowShare3 } \\
\text { Effic-factor1/Effic-factor2/ } \\
\text { Effic-factor3 }\end{array}$ & 0.182717 & 0.033385 & 0.89128 & 0.382006 \\
\hline $\begin{array}{l}\text { Expert catalogue } \\
\text { Increased competitiveness }\end{array}$ & $\begin{array}{l}\text { EtacitK1/EtacitK2/EtacitK3 } \\
\text { Effic-factor1/Effic-factor2/ } \\
\text { Effic-factor3 }\end{array}$ & -0.449430 & 0.201987 & -2.41280 & 0.024203 \\
\hline $\begin{array}{l}\text { Expert catalogue } \\
\text { Increased quality of products }\end{array}$ & $\begin{array}{l}\text { EtacitK1/EtacitK2/EtacitK3 } \\
\text { Effic-factor1/Effic-factor2/ } \\
\text { Effic-factor3 }\end{array}$ & -0.422687 & 0.178665 & -2.23678 & 0.035287 \\
\hline $\begin{array}{l}\text { Expert catalogue } \\
\text { Increased customer Satisfaction }\end{array}$ & $\begin{array}{l}\text { EtacitK1/EtacitK2/EtacitK3 } \\
\text { Effic-factor1/Effic-factor2/ } \\
\text { Effic-factor3 }\end{array}$ & -0.261305 & 0.068280 & -1.29828 & 0.207059 \\
\hline $\begin{array}{l}\text { Expert catalogue } \\
\text { Faster response to customer needs }\end{array}$ & $\begin{array}{l}\text { EtacitK1/EtacitK2/EtacitK3 } \\
\text { Effic-factor1/Effic-factor2/ } \\
\text { Effic-factor3 }\end{array}$ & -0.292037 & 0.085286 & -1.46440 & 0.156621 \\
\hline $\begin{array}{l}\text { Expert catalogue } \\
\text { Easier and faster access to the } \\
\text { information }\end{array}$ & $\begin{array}{l}\text { EtacitK1/EtacitK2/EtacitK3 } \\
\text { Effic-factor1/Effic-factor2/ } \\
\text { Effic-factor3 }\end{array}$ & -0.025540 & 0.000652 & -0.12253 & 0.903546 \\
\hline $\begin{array}{l}\text { Expert catalogue } \\
\text { Increased employee motivation }\end{array}$ & $\begin{array}{l}\text { EtacitK1/EtacitK2/EtacitK3 } \\
\text { Effic-factor1/Effic-factor2/ } \\
\text { Effic-factor3 }\end{array}$ & 0.046701 & 0.002181 & 0.22422 & 0.824568 \\
\hline $\begin{array}{l}\text { Expert catalogue } \\
\text { Saving time }\end{array}$ & $\begin{array}{l}\text { EtacitK1/EtacitK2/EtacitK3 } \\
\text { Effic-factor1/Effic-factor2/ } \\
\text { Effic-factor3 }\end{array}$ & 0.008388 & 0.000070 & 0.04023 & 0.968259 \\
\hline $\begin{array}{l}\text { Expert catalogue } \\
\text { Cost reduction }\end{array}$ & $\begin{array}{l}\text { EtacitK1/EtacitK2/EtacitK3 } \\
\text { Effic-factor1/Effic-factor2/ } \\
\text { Effic-factor3 }\end{array}$ & -0.322164 & 0.103789 & -1.63206 & 0.116285 \\
\hline $\begin{array}{l}\text { Expert catalogue } \\
\text { Increased work productivity }\end{array}$ & $\begin{array}{l}\text { EtacitK1/EtacitK2/EtacitK3 } \\
\text { Effic-factor1/Effic-factor2/ } \\
\text { Effic-factor3 }\end{array}$ & -0.091012 & 0.008283 & -0.43830 & 0.665260 \\
\hline $\begin{array}{l}\text { Instant messaging; dedicated } \\
\text { information system } \\
\text { Increased competitiveness }\end{array}$ & $\begin{array}{l}\text { ExplicitK1/ExplicitK2/ExplicitK3 } \\
\text { Effic-factor1/Effic-factor2/ } \\
\text { Effic-factor3 }\end{array}$ & -0.102537 & 0.010514 & -0.49435 & 0.625745 \\
\hline $\begin{array}{l}\text { Instant messaging; dedicated } \\
\text { information system } \\
\text { Increased quality of products }\end{array}$ & $\begin{array}{l}\text { ExplicitK1/ExplicitK2/ExplicitK3 } \\
\text { Effic-factor1/Effic-factor2/ } \\
\text { Effic-factor3 }\end{array}$ & 0.214147 & 0.045859 & 1.05140 & 0.303996 \\
\hline $\begin{array}{l}\text { Instant messaging; dedicated } \\
\text { information system } \\
\text { Increased customer Satisfaction }\end{array}$ & $\begin{array}{l}\text { ExplicitK1/ExplicitK2/ExplicitK3 } \\
\text { Effic-factor1/Effic-factor2/ } \\
\text { Effic-factor3 }\end{array}$ & 0.186641 & 0.034835 & 0.91111 & 0.371688 \\
\hline $\begin{array}{l}\text { Instant messaging; dedicated } \\
\text { information system } \\
\text { Faster response to customer needs }\end{array}$ & $\begin{array}{l}\text { ExplicitK1/ExplicitK2/ExplicitK3 } \\
\text { Effic-factor1/Effic-factor2/ } \\
\text { Effic-factor3 }\end{array}$ & 0.137931 & 0.019025 & 0.66788 & 0.510859 \\
\hline $\begin{array}{l}\text { Instant messaging; dedicated } \\
\text { information system } \\
\text { Easier and faster access to the } \\
\text { information }\end{array}$ & $\begin{array}{l}\text { ExplicitK1/ExplicitK2/ExplicitK3 } \\
\text { Effic-factor1/Effic-factor2/ } \\
\text { Effic-factor3 }\end{array}$ & 0.224533 & 0.050415 & 1.10504 & 0.280569 \\
\hline $\begin{array}{l}\text { Instant messaging. dedicated } \\
\text { information system } \\
\text { Increased employee motivation }\end{array}$ & $\begin{array}{l}\text { ExplicitK1/ExplicitK2/ExplicitK3 } \\
\text { Effic-factor1/Effic-factor2/ } \\
\text { Effic-factor3 }\end{array}$ & -0.111666 & 0.012469 & -0.53890 & 0.595134 \\
\hline $\begin{array}{l}\text { Instant messaging; dedicated } \\
\text { information system } \\
\text { Saving time }\end{array}$ & $\begin{array}{l}\text { ExplicitK1/ExplicitK2/ExplicitK3 } \\
\text { Effic-factor1/Effic-factor2/ } \\
\text { Effic-factor3 }\end{array}$ & 0.447911 & 0.200625 & 2.40260 & 0.024745 \\
\hline $\begin{array}{l}\text { Instant messaging; dedicated } \\
\text { information system } \\
\text { Cost reduction }\end{array}$ & $\begin{array}{l}\text { ExplicitK1/ExplicitK2/ExplicitK3 } \\
\text { Effic-factor1/Effic-factor2/ } \\
\text { Effic-factor3 }\end{array}$ & 0.258566 & 0.066856 & 1.28369 & 0.212033 \\
\hline $\begin{array}{l}\text { Instant messaging; dedicated } \\
\text { information system } \\
\text { Increased work productivity }\end{array}$ & $\begin{array}{l}\text { ExplicitK1/ExplicitK2/ExplicitK3 } \\
\text { Effic-factor1/Effic-factor2/ } \\
\text { Effic-factor3 }\end{array}$ & 0.242918 & 0.059009 & 1.20097 & 0.241986 \\
\hline
\end{tabular}


To determine the nature of this significant interaction, the study plots the effect (see Fig. 3 and Fig. 4): company efficiency: increased competitiveness $=2.5821-$ 0.3378 using the expert catalogue and company efficiency: increased quality of products $=2.7634-0.3282$ using the expert catalogue. So, according to these results, company efficiency clearly decreases with tacit knowledge sharing in Polish manufacturing companies. This finding offers no support for hypothesis $\mathrm{H} 2 \mathrm{a}$.

For $\mathrm{H} 2 \mathrm{~b}$, I examined the effects of explicit knowledge sharing on company efficiency respectively. As Table 2 and Fig. 5 show, the effect of explicit knowledge shar- ing on company efficiency: saving time, has a value of 0.447911 and is statistically significant, providing support for $\mathrm{H} 2 \mathrm{~b}$. To determine the nature of this significant interaction, the study plots the effect (see Fig. 5): company efficiency: saving time $=1.1893+0.43319$ using an instant messaging dedicated information system. The company efficiency: saving time clearly increases with explicit knowledge sharing in Polish manufacturing companies, when facing high values for using an instant messaging dedicated information system.

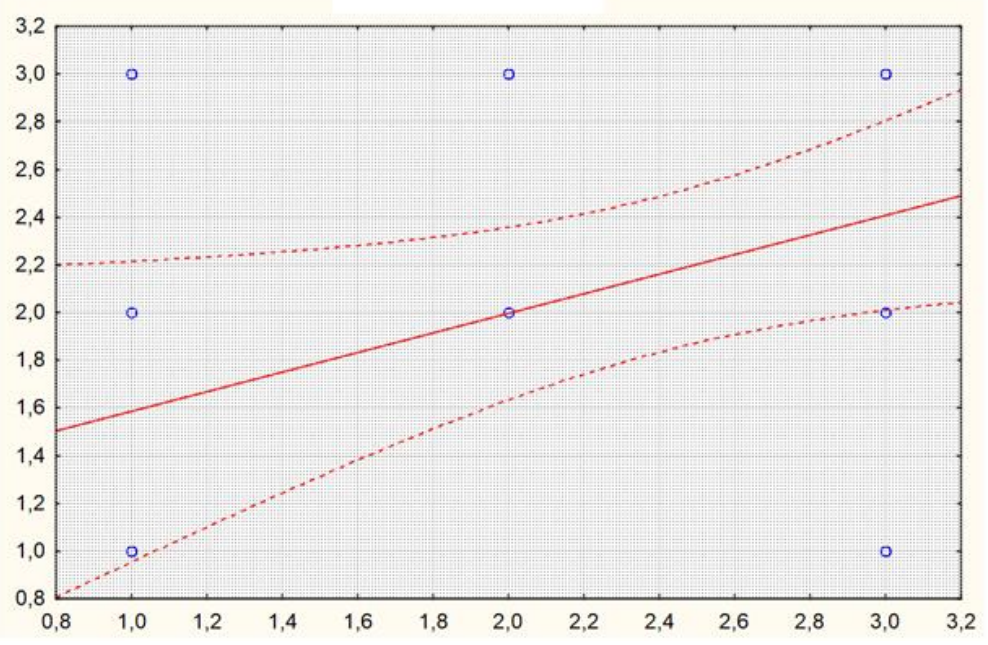

Figure 2. Interactions involving knowledge sharing and company efficiency

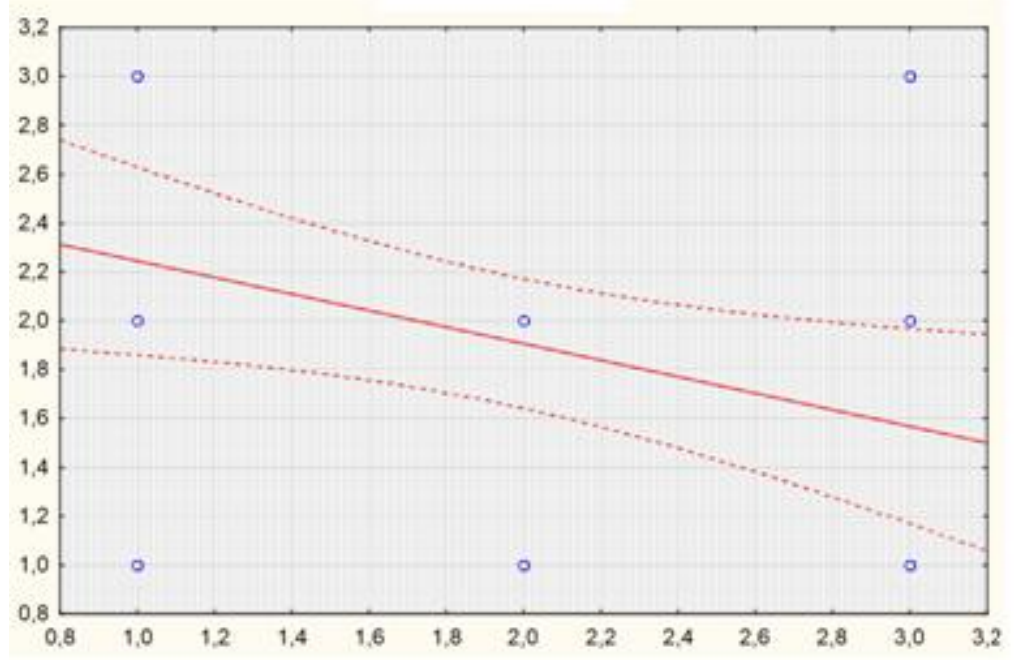

Figure 3. Interactions involving tacit knowledge sharing and company efficiency (increased competitiveness) 


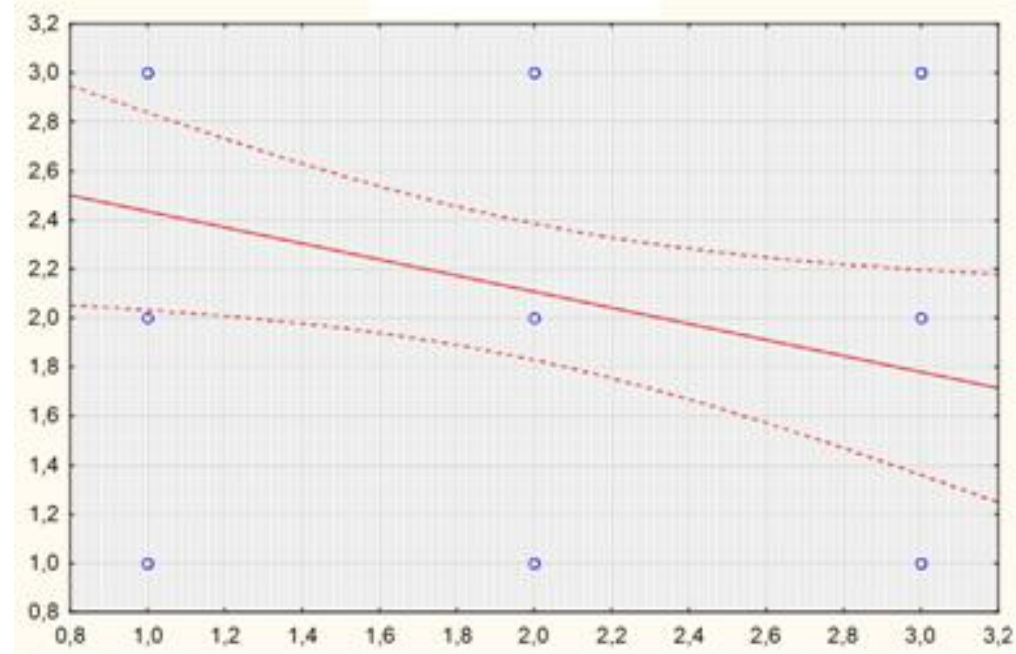

Figure 4. Interactions involving tacit knowledge sharing and company efficiency (increased quality of products)

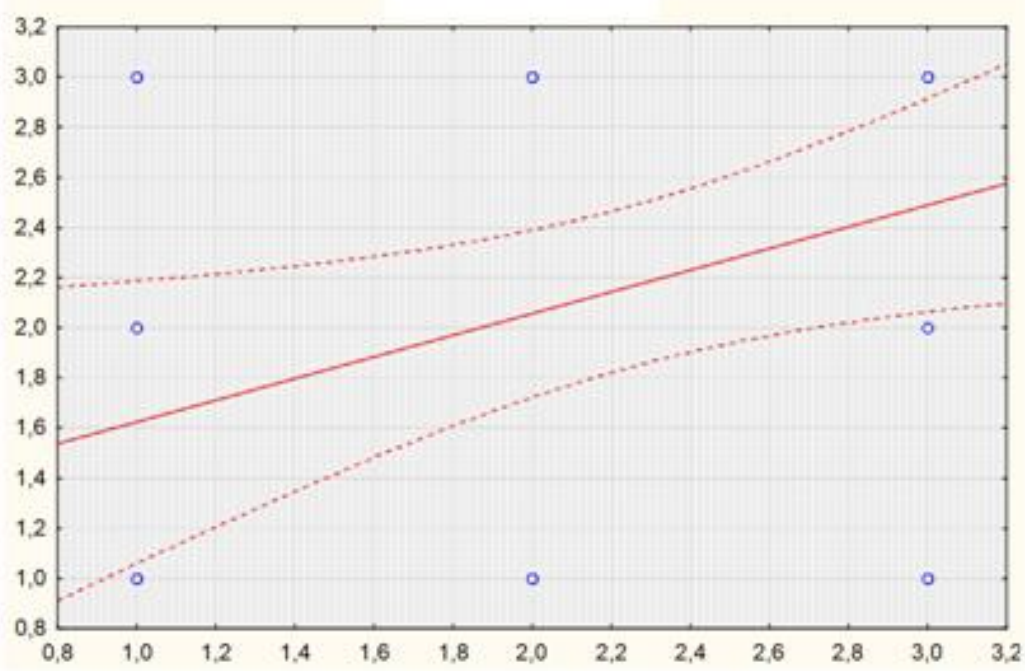

Figure 5. Interactions involving explicit knowledge sharing and company efficiency

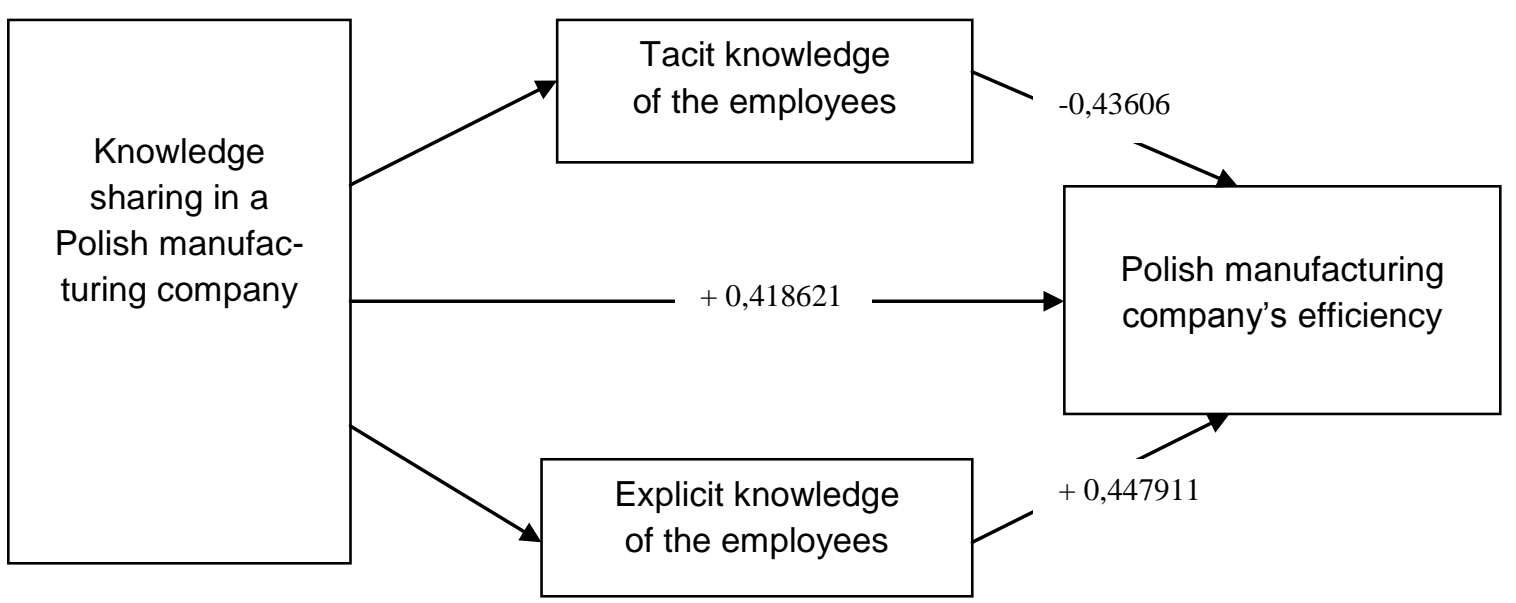

Figure 6. Analysis of the results 
This study does not just testify to the influence of knowledge sharing on company efficiency, but also explores how this mechanism works through the use of Web 2.0 technologies for knowledge sharing in enterprises. The structural model results are shown in Fig. 6.

\section{$5 \quad$ Conclusions and recommendations}

This section of the paper summarises the new findings of this study and discusses the implications.

This research analyses the effects of knowledge sharing in Polish manufacturing companies. It is based on using a comprehensive framework that integrates three research streams: tacit and explicit knowledge and company efficiency.

Some studies empirically discussed the effects of knowledge sharing on various aspects. By proposing a model which addresses the influence of explicit and tacit knowledge sharing on the benefits of the use of Web 2.0 technologies for knowledge sharing in enterprises, this study contributes to filling the gap which exists in the literature.

The empirical findings of this study confirm the general hypothesis, except the second part as it was found that tacit knowledge sharing decreases company efficiency. It is therefore clear that discerning the type of knowledge sharing involved can significantly deepen our understanding of the contingent effect that such sharing has on company efficiency. Moreover, this study suggests that it may not be the best idea to implement Web 2.0 technologies that facilitate the sharing of tacit knowledge, because they could decrease company efficiency.

Like all studies, this one has certain limitations that further research should aim to overcome. Firstly, because the intention is to analyse knowledge sharing, this study focuses on Polish manufacturing industries which traditionally use some form of Web 2.0 technology. It would be unwise to generalise the findings too broadly to other enterprises.

Furthermore, all the variables are measured at the same moment in time. So, it would be useful to provide such research over a longer time period and at different stages. These conclusions and limitations suggest proposals for future research direction, such as exploring additional factors that could improve the effect of knowledge sharing on company efficiency.

\section{$6 \quad$ References}

[1] Babcock P. - Shedding light on knowledge management [in] HR Magazine, Vol. 49, No. 5, 20040, pp. $46-50$.

[2] Barson R.J., Foster G., Struck T., Ratchev S., Pawar K. - Inter-and intra-organisational barriers to sharing knowledge in the extended supply-chain [in] Proceedings of the eBusiness and eWork (e2000), Madrid, Spain, 2000.

[3] Boulos M., Wheeler S. - The emerging Web 2.0 social software: an enabling suite of sociable technologies in health and health care education [in] Health Information and Libraries Journal, Vol. 24, No. 1, 2007, pp. 2-23.

[4] Bureš V. - Cultural barriers in knowledge sharing [in] E+M economics and management, Vol. 6, 2003, pp. 57-62.

[5] Chaudhry A.S. - Knowledge sharing practices in Asian institutions: A multi-cultural perspective from Singapore [in] Proceedings of 71th IFLA general conference and council, Oslo, Norway, 2005.

[6] Coakes E. - Storing and sharing knowledge: Supporting the management of knowledge made explicit in transnational organizations [in] The Learning Organization, Vol. 13, 2006, pp. 579-593.

[7] Devaraj S., Kohli R. - Performance impacts of information technology: Is actual usage the missing link? [in] Management Science, Vol. 49, No. 3, 2003, pp. 273-289.

[8] Erat P., Desouza K., Schafer-Jugel A., Kurzawa M. - Business customer communities and knowledge sharing: Studying the critical issues [in] European Journal of Information System, Vol. 15, 2006, pp. 511-524.

[9] Etzioni A. - Modern organizations. Englewood Cliffs, NJ: Prentice Hall, 1964.

[10] Grant R.M. - Toward a knowledge-based theory of the firm [in] Strategic Management Journal, Vol. 17, No. 7, 1996, pp. 109-122.

[11] Han B.M., Anantatmula V.S. Knowledge sharing in large IT organizations: A case study [in] VINE, Vol. 37, No. 4, 2007, pp. 421-439.

[12] Hemmi A., Bayne S., Land R. - The appropriation and repurposing of social technologies in higher education [in] Journal of Computer Assisted Learning, Vol. 25, No. 1, 2009, pp. 19-30. 
[13] Huang Q., Davison R.M., Gu J. - The impact of trust, guanxi orientation and face on the intention of Chinese employees and managers to engage in peer-to-peer tacit and explicit knowledge sharing [in] Information Systems Journal, 2010.

[14] Huang Y.M., Chen J.N., Kuo Y.H., Jeng Y.L. An intelligent human-expert forum system based on fuzzy information retrieval technique [in] Expert Systems with Applications, Vol. 34, No. 1, 2008, pp. 446-458.

[15] Johnson D. - Computer ethics [in] The Blackwell guide to the philosophy of computer and information (ed. Floridi L.). Blackwell Publishers Limited, Oxford, UK, 2004, pp. 65-75.

[16] Kane G.C., Fichman R.G. - The shoemaker's children: using Wikis for information systems teaching, research, and publication (includes comments and editorial note) [in] MIS Quarterly, Vol. 33, No. 1, 2009, pp. 1-22.

[17] Kim S.-J., Hong J.-Y., Suh E.-H. - A diagnosis framework for identifying the current knowledge sharing activity status in a community of practice [in] Expert Systems with Applications, Vol. 39, No. 18, 2012, pp. 13093-13107.

[18] Law C.C.H., Ngai E.W.T. - An empirical study of the effects of knowledge sharing and learning behaviors on firm performance [in] Expert Systems with Applications, Vol. 34, No. 4, 2008, pp. 23422349.

[19] Li C., Stromberg C. - The ROI of blogging. Forrester Research, 2007.

[20] Li H., Dong X., Zuo M. - Knowledge Management in Theory and Practice. Huayi Press, Beijing, 2002.

[21] Lin H. F. - Knowledge sharing and firm innovation capability: An empirical study [in] International Journal of Manpower, Vol. 28, No. 3/4, 2007, pp. 315-332.

[22] Mesmer-Magnus J.R., DeChurch L.A. - Information sharing and team performance: A metaanalysis [in] Journal of Applied Psychology, Vol. 94, 2009, pp. 535-546.

[23] Mujadi H., Takeda H., Shakya A., Kawamoto S., Kobayashi S., Fujiyama A., Ando K. - Semantic Wiki as a lightweight knowledge management system [in] Semantic Web - Aswc 2006, Vol. 4185, 2006), pp. 65-71.

[24] Nonaka I., Takeuchi H. - The knowledge-creating company: How Japanese companies create the dy- namics of innovation. Oxford University Press, USA, 1995.

[25] Paroutis S., Al Saleh A. - Determinants of knowledge sharing using Web 2.0 technologies [in] Journal of Knowledge Management, Vol. 13, 2009, pp. 52-63.

[26] Patalas-Maliszewska J. - Knowledge Worker Management: Value Assessment, Methods, and Application Tools. Springer, Heidelberg, 2013.

[27] Polanyi M. - Human knowledge. The University of Chicago Press, Chicago, 1966.

[28] Ray G., Muhanna W.A., Barney J.B. - Information technology and the performance of the customer service process: A resource-based analysis [in] MIS Quarterly, Vol. 29, No. 4, 2005, pp. 625-652.

[29] Simon H.A. - The new science of management decision. Revised edition, Englewood, 1960.

[30] Syuntyurenko O.V. - Information Society and Information Sciences [in] Vestnik Ross. Fond Fund, Vol. 3, No. 17, 1999, pp. 4-7.

[31] Tampoe M. - Motivating knowledge workers The challenge for the 1990s [in] Long Range Planning, Vol. 26, No. 3, 1993, pp. 49-55.

[32] Teece D.J. - Business models, business strategy and innovation [in] Long Range Planning, Vol. 43, 2010, pp. 172-194.

[33] Upton D.M. - What really makes factory flexible [in] Harvard Business Review, No. 07/08, 1995, pp. 74-84.

[34] Velasquez J.D., Lara M.A., Shimon Y.N. - Systematic resolution of conflict in collaborative facilities design [in] International Journal of Production Economics, Vol. 116, No. 1, 2008, pp. 139-153.

[35] Zahra S.A., Neubaum D.O., Larrañeta B. Knowledge sharing and technological capabilities: The moderating role of family involvement [in] Journal of Business Research, Vol. 60, No. 10, 2007, pp. 1070-1079.

[36] Zhang C., Hu Z., Gu F.F. - Intra- and interfirm coordination of export manufacturers: A cluster analysis of indigenous Chinese exporters [in] Journal of International Marketing, Vol. 16, No. 3 2008, pp. 108-135.

[37] Zott C., Amit R. - Business model design and the performance of entrepreneurial firms [in] Organization Science, Vol. 18, No. 2, 2007, pp. 181-199. 